\title{
Metabotropic Glutamate Receptor 2/3 (mGluR2/3) Activation Suppresses TRPV1 Sensitization in Mouse, But Not Human, Sensory Neurons
}

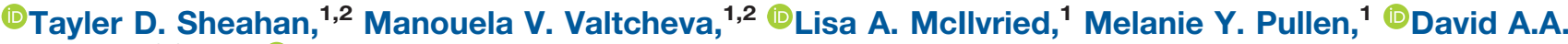 \\ Baranger, ${ }^{2,3}$ and ${ }^{-}$Robert W. Gereau IV ${ }^{1}$
}

\section{DOI:http://dx.doi.org/10.1523/ENEURO.0412-17.2018}

\begin{abstract}
${ }^{1}$ Washington University Pain Center and Department of Anesthesiology, Washington University School of Medicine, St. Louis, Missouri 63110, ${ }^{2}$ Washington University Program in Neuroscience, Washington University School of Medicine, St. Louis, Missouri 63110, and ${ }^{3}$ BRAIN Laboratory, Department of Psychological and Brain Sciences, Washington University in St. Louis, St. Louis, Missouri 63130
\end{abstract}

\begin{abstract}
The use of human tissue to validate putative analgesic targets identified in rodents is a promising strategy for improving the historically poor translational record of preclinical pain research. We recently demonstrated that in mouse and human sensory neurons, agonists for metabotropic glutamate receptors 2 and 3 (mGluR2/3) reduce membrane hyperexcitability produced by the inflammatory mediator prostaglandin $\mathrm{E}_{2}\left(\mathrm{PGE}_{2}\right)$. Previous rodent studies indicate that mGluR2/3 can also reduce peripheral sensitization by suppressing inflammation-induced sensitization of TRPV1. Whether this observation similarly translates to human sensory neurons has not yet been tested. We found that activation of mGluR2/3 with the agonist APDC suppressed $\mathrm{PGE}_{2}$-induced sensitization of TRPV1 in mouse, but not human, sensory neurons. We also evaluated sensory neuron expression of the gene transcripts for mGluR2 (Grm2), mGluR3 (Grm3), and TRPV1 (Trpv1). The majority of Trpv1+ mouse and human sensory neurons expressed Grm2 and/or Grm3, and in both mice and humans, Grm2 was expressed in a greater percentage of sensory neurons than $\mathrm{Grm} 3$. Although we demonstrated a functional difference in the modulation of TRPV1 sensitization by mGluR2/3 activation between mouse and human, there were no species differences in the gene transcript colocalization of mGluR2 or mGluR3 with TRPV1 that might explain this functional difference. Taken together with our previous work, these results suggest that mGluR2/3 activation suppresses only some aspects of human sensory neuron sensitization caused by $\mathrm{PGE}_{2}$. These differences have implications for potential healthy human voluntary studies or clinical trials evaluating the analgesic efficacy of mGluR2/3 agonists or positive allosteric modulators.
\end{abstract}

Key words: Dorsal root ganglia; glutamate; human neurons; metabotropic; nociceptors; pain

\section{Significance Statement}

Species differences between rodents and humans have been proposed to contribute to the low success rate of analgesic drug development. This work utilizes primary human neurons to assess the translational potential of metabotropic glutamate receptor $2 / 3$ (mGluR2/3), which have been identified as modulators of pain in a variety of rodent models. In mouse sensory neurons, we found that activation of mGluR2/3 blocked inflammation-induced sensitization of the nonselective cation channel TRPV1. In contrast, this effect was not observed in human sensory neurons. These results indicate that mechanisms of peripheral analgesia are not entirely conserved across species. More broadly, our findings demonstrate that using human tissue to validate analgesic targets identified in rodents is an important step in the translational research process. 


\section{Introduction}

Species differences between rodents and humans have been proposed to contribute to the low success rate of analgesic drug development (Le Bars et al., 2001; Whiteside and Kennedy, 2010; Woolf, 2010; Mao, 2012). In preclinical research, putative analgesics are often identified and exclusively evaluated in rodent tissues and/or pain models before entering clinical trials, in which such drugs seldom demonstrate efficacy (Kissin, 2010; Woolf, 2010; Moore et al., 2013). Therefore, using primary human neurons to validate preclinical rodent findings is an appealing strategy to improve the translational success of basic pain research findings. With this goal in mind, we and others have established approaches to obtain and use human sensory neurons to better understand human nociceptor physiology (Baumann et al., 1996; Anand et al., 2006; Davidson et al., 2014; Han et al., 2015; Zhang et al., 2015; Sapio et al., 2016; Valtcheva et al., 2016; Rostock et al., 2017).

The group II metabotropic glutamate receptors (mGluRs) have recently been identified as putative targets for pain relief in rodents (Sharpe et al., 2002; Simmons et al., 2002; Yang and Gereau, 2002, 2003; Jones et al., 2005; Du et al., 2008; Osikowicz et al., 2008; Carlton et al., 2009, 2011; Zammataro et al., 2011; Asseri et al., 2015; Kolber, 2015; Chiechio, 2016; Johnson et al., 2017). mGluR2 and mGluR3 are seven transmembrane domain $\mathrm{G}_{\mathrm{i}}$-protein coupled receptors that decrease cAMP formation, activate potassium channels, and inhibit voltage-gated calcium channels to reduce neuronal excitability and synaptic transmission (Conn and Pin, 1997; Johnson and Schoepp, 2008). Although group II mGluRs are expressed at each level of the pain neuraxis (Petralia et al., 1996; Tang and Sim, 1999; Carlton et al., 2001; Varney and Gereau, 2002; Carlton and Hargett, 2007; Boye Larsen et al., 2014; Kolber, 2015; Chiechio, 2016; Davidson et al., 2016), several lines of evidence suggest that activation of

Received November 29, 2017; accepted February 7, 2018; First published March 5, 2018.

The authors declare no competing financial interests.

Author contributions: T.D.S. and R.W.G. IV designed research; T.D.S., M.V.V., L.A.M., and M.Y.P. performed research; T.D.S. and D.A.A.B. analyzed data; T.D.S. wrote the paper

Conflict of Interest: Authors report no conflict of interest

This work was supported by NINDS R01NS042595 to RWG, NINDS F31NS089130 to MVV, NIDA 2T32 DA007261-26 to LAM, and NSF DGE1745038 to DAAB

Acknowledgments: We deeply thank the donors and their loved ones for making this research possible. We are grateful to Mid-America Transplant for allowing access to organ donors and the use of facilities. John Lemen provided instrumental help during human DRG surgical extractions. We thank Sherri K. Vogt and Kajanna C. McKenzie for managing and caring for animal colonies. The entire Gereau Lab gave helpful comments and critiques. Judith P. Golden and Bryan A. Copits provided insightful feedback on this manuscript.

Correspondence should be addressed to Robert W. Gereau IV, PhD, Director I Washington University Pain Center, Dr. Seymour and Rose T. Brown Professor, Department of Anesthesiology, Washington University School of Medicine, $660 \mathrm{~S}$. Euclid Avenue, Campus Box 8054, St. Louis, MO 63110, Telephone number: (314) 362-8312, Fax Number: (314) 362-8334, E-mail: gereaur@wustl.edu.

DOI:http://dx.doi.org/10.1523/ENEURO.0412-17.2018

Copyright @ 2018 Sheahan et al.

This is an open-access article distributed under the terms of the Creative Commons Attribution 4.0 International license, which permits unrestricted use, distribution and reproduction in any medium provided that the original work is properly attributed.
mGlu2 and mGlu3 receptors in peripheral sensory neurons is sufficient for analgesia. For instance, in rodent inflammatory pain models, pharmacological activation of mGluR2/3 expressed on peripheral primary afferents can attenuate pain-like behavior by suppressing sensory neuron sensitization in response to algogens and inflammatory mediators (Yang and Gereau, 2002; Du et al., 2008; Carlton et al., 2011, 2009; Asseri et al., 2015; Davidson et al., 2016). Conversely, pharmacological inhibition of peripheral mGluR2/3 can prolong pain-like behavior and increase sensory neuron activity, suggesting that endogenous activation of mGluR2/3 is analgesic (Yang and Gereau, 2003; Carlton et al., 2011). Given the centrally mediated adverse effects of existing analgesics such as opioid addiction and abuse, peripheral analgesic targets are of particular interest.

Our recent studies on cultured human dorsal root ganglia (DRG) neurons suggest peripheral mGlu2/3 receptors may be clinically relevant analgesic targets. We demonstrated both anatomical and functional expression of group II mGluRs in human DRG (Davidson et al., 2016). Importantly, as in mice, mGluR2/3 activation blocked human nociceptor membrane hyperexcitability produced by the inflammatory mediator prostaglandin E2 ( $\left.\mathrm{PGE}_{2}\right)$, indicating that a mechanism for peripheral analgesia may be conserved across species (Davidson et al., 2016). Rodent studies suggest that mGlu2/3 receptors expressed on sensory neuron peripheral terminals can also reduce sensory neuron sensitization by suppressing sensitization of TRPV1 (Yang and Gereau, 2002; Du et al., 2008; Carlton et al., 2009, 2011), a nonselective cation channel that detects noxious stimuli and is critical for inflammationinduced peripheral sensitization (Caterina et al., 1997, 2000; Davis et al., 2000; Moriyama et al., 2005). The present study tested whether the same mechanism is conserved in humans. We used sensory neurons obtained from organ donors without chronic pain to determine whether mGluR2/3 activation blocks inflammation-induced sensitization of TRPV1 in human neurons. We demonstrate that group II mGluR activation suppresses $\mathrm{PGE}_{2}$ induced sensitization of TRPV1 calcium responses in mouse, but not human, sensory neurons. Interestingly, this functional difference was not explained by species differences in coexpression of the TRPV1 gene transcript with mGlu2 or mGlu3 receptor gene transcripts.

\section{Materials and Methods}

\section{Animals}

All experiments were performed in compliance with protocols approved by the Animal Studies Committee of Washington University in St. Louis (Protocol nos. 20150246 and 20160097). Experiments were conducted on 5-8-wkold C57BL/6J male and female mice (Jackson Laboratory, RRID:IMSR_JAX000664). Mice were housed in an animal facility with a 12-h light-dark cycle and given food and water ad libitum.

\section{Donors}

Human tissue was obtained in compliance with procedures approved by Mid-America Transplant (St. Louis, 
Table 1. Donor information and tissue uses

\begin{tabular}{lllll}
\hline & & & \multicolumn{1}{c}{ Cause } & \\
Donor Age, y & Sex & Race of death & \multicolumn{1}{c}{ Tissue uses } \\
1 & 21 & Male & White Stroke & $\mathrm{Ca}^{2+}$ imaging \\
2 & 55 & Female & White Stroke & $\mathrm{Ca}^{2+}$ imaging, FISH \\
3 & 22 & Male & Black Anoxia & $\mathrm{Ca}^{2+}$ imaging \\
4 & 44 & Female White Stroke & $\mathrm{Ca}^{2+}$ imaging \\
5 & 12 & Female White Anoxia & $\mathrm{Ca}^{2+}$ imaging, FISH \\
6 & 26 & Male & White Head trauma $\mathrm{Ca}^{2+}$ imaging, FISH \\
7 & 18 & Female White Head trauma $\mathrm{Ca}^{2+}$ imaging, FISH \\
8 & 18 & Male & White Head trauma $\mathrm{Ca}^{2+}$ imaging, FISH \\
\hline
\end{tabular}

y, year; FISH, fluorescent in situ hybridization.

MO), and the Human Research Protection Office at Washington University in St. Louis provided an International Review Board waiver. Human DRG were obtained from organ donors with full legal consent for use of tissue for research. Only donors without a history of chronic pain were used in this study (Table 1).

\section{Mouse DRG cultures}

For each tissue preparation, two age- and sex-matched mice were killed by live decapitation, and cervical through lumbar DRG were removed and pooled together. DRG were incubated in papain (45 U, Worthington) for $20 \mathrm{~min}$ at $37^{\circ} \mathrm{C}, 5 \% \mathrm{CO}_{2}$. DRG were then rinsed and incubated in collagenase (1.5 mg/mL, Sigma-Aldrich) for $20 \mathrm{~min}$. Both enzyme solutions were made up in $\mathrm{Ca}^{2+}$ - and $\mathrm{Mg}^{2+}$-free Hanks' buffered salt solution (Corning) with $10 \mathrm{~mm}$ Hepes (Sigma-Aldrich). DRG were manually triturated with firepolished Pasteur pipettes (VWR) to dissociate neurons, passed through a $40-\mu \mathrm{m}$ filter (VWR), and plated onto poly-D-lysine/collagen (Sigma-Aldrich)-coated 12-mm glass coverslips (Thermo Fisher Scientific). Neurons were maintained in culture for $2 \mathrm{~d}$ in Neurobasal A medium (Invitrogen) supplemented with $100 \mathrm{U} / \mathrm{mL}$ penicillin/streptomycin (Corning), 2 mm GlutaMAX (Life Technologies), 2\% B27 (Gibco), and 5\% fetal bovine serum (Gibco).

\section{Human DRG cultures}

Human DRG from the first through fifth lumbar vertebrae were surgically extracted and cultured as described in detail previously (Valtcheva et al., 2016). Briefly, after extraction, fat and dura were trimmed away from the ganglia. DRG were minced, incubated in papain for $1 \mathrm{~h}$, rinsed, and incubated in collagenase for $1 \mathrm{~h}$. Both enzyme solutions were made up in an N-methyl-D-glucamine artificial cerebrospinal fluid solution (Sigma-Aldrich). DRG were manually triturated with fire-polished Pasteur pipettes to dissociate neurons, passed through a $100-\mu \mathrm{m}$ filter (VWR), and plated onto poly-D-lysine/collagen-coated $12-\mathrm{mm}$ glass coverslips. Neurons were maintained in culture for up to $9 \mathrm{~d}$ in the medium described above (mean time in culture: $6 \mathrm{~d}$ ). Every $3 \mathrm{~d}$, half of the culture medium was replaced with fresh media to ensure neuronal health.

\section{Calcium imaging}

Calcium imaging experiments were performed on mouse and human sensory neurons on days in vitro (DIV) 2 and 3-9, respectively. Acutely after culturing human
DRG neurons, satellite glial encased neurons, and thus accurate physiology experiments could not be performed until the glial peeled off and exposed the neuron plasma membrane, which occurred after 3-4 DIV as reported previously (Valtcheva et al., 2016). Mouse calcium imaging experiments were therefore initially performed on DIV 4. Strikingly, we found that only $2 \%$ of mouse DRG neurons responded to $100 \mathrm{nM}$ capsaicin on DIV 4, which we interpreted as a functional downregulation of TRPV1. Therefore, we chose to perform mouse calcium imaging experiments on DIV 2 such that recordings were not performed acutely after culturing neurons, yet were completed before TRPV1 functional downregulation.

Cultured neurons from mice and humans were incubated with $3 \mu \mathrm{g} / \mathrm{mL}$ of the ratiometric calcium indicator Fura-2 AM (Life Technologies) for $45 \mathrm{~min}$. Neurons were then incubated in external solution for $15 \mathrm{~min}$ to allow for de-esterification of Fura-2 AM. External solution consisted of (in $\mathrm{mm}$ ): $130 \mathrm{NaCl}, 5 \mathrm{KCl}, 2 \mathrm{CaCl}_{2}, 1 \mathrm{MgCl}_{2}, 30$ glucose, and 10 Hepes. For recordings, coverslips were placed into a chamber and perfused with room temperature external solution. Cells were viewed under an inverted microscope (Olympus Optical), and fluorescent images were acquired every $2 \mathrm{~s}$ using a Hamamatsu ORCA camera (Hamamatsu). SimplePCI Software (HClmage, Hamamatsu) was used to identify regions of interest surrounding Fura-2 AM-loaded neurons a priori and to record fluorescence emission at alternating excitation wavelengths of 357 and $380 \mathrm{~nm}$.

The experimental protocol entailed a 2-min baseline in external solution followed by a 20-s bath application of $100 \mathrm{~nm}$ capsaicin (Sigma-Aldrich), a 3-min wash with external solution, then a treatment condition entailing application of either $7 \mathrm{~min}$ of vehicle (external solution), $6 \mathrm{~min}$ of $1 \mu \mathrm{M}$ prostaglandin E2 ( $\mathrm{PGE}_{2}$, Tocris), or 1 min of $10 \mu \mathrm{M}$ $(2 \mathrm{R}, 4 \mathrm{R})$-4-aminopyrrolidine-2,4-dicarboxylate (APDC, Tocris) alone followed by 6 min of $10 \mu \mathrm{M}$ APDC plus $1 \mu \mathrm{M}$ $\mathrm{PGE}_{2}$. Immediately after treatment, a second pulse of 100 nм capsaicin was bath-applied, neurons were washed for 6 min with external solution, and a 10-s pulse of $50 \mathrm{~mm}$ $\mathrm{KCl}$ was applied to test for cell viability. At least 2 treatment conditions were tested for a given mouse or donor tissue preparation. All drugs were diluted in external solution and bath-applied at a rate of $2 \mathrm{~mL} / \mathrm{min}$. Stock solutions of $2.8 \mathrm{~mm} \mathrm{PGE}_{2}$ and $10 \mathrm{~mm}$ APDC were made up in DMSO and water, respectively. Peak calcium responses were calculated by dividing the absolute increase in Fura-2 AM signal after stimulus application by the proceeding 30-s baseline Fura-2 AM signal. The response threshold to capsaicin was defined as an increase of $\geq 10 \%$ from baseline signal. Cells that did not respond to high $\mathrm{KCl}$ were excluded from calcium imaging analysis.

\section{Fluorescent in situ hybridization (RNAscope)}

At the conclusion of mouse and human calcium imaging experiments, neurons were fixed on ice with $4 \%$ paraformaldehyde/4\% sucrose for $15 \mathrm{~min}$ and washed with PBS. Fluorescent in situ hybridization (FISH) studies were performed according to the protocol for cultured adherent cells using the RNAscope Multiplex Fluorescent Assay 
Table 2. RNAscope probes used for FISH

\begin{tabular}{ll}
\hline Target & Catalog no. \\
Mm-Trpv1 & 313331 \\
Mm-Grm2-C3 & $317831-\mathrm{C} 3$ \\
Mm-Grm3-C2 & $317821-\mathrm{C} 2$ \\
Positive Control Probe-Mm & 320881 \\
Hs-TRPV1 & 415381 \\
Hs-GRM2-C3 & $589771-\mathrm{C} 3$ \\
Hs-GRM3-C2 & $500181-\mathrm{C} 2$ \\
Positive Control Probe-Hs & 320861 \\
Negative Control Probe & 320871 \\
\end{tabular}

Mm, mus musculus; Hs, homo sapiens; C2, channel 2; C3, channel 3.

(Advanced Cell Diagnostics) with minor modifications. After dehydration and rehydration of cells in ethanol, glass coverslips were mounted onto glass slides using ethyl cyanoacrylate. Neurons were treated with protease III diluted 1:10 (mouse) or 1:5-7.5 (human) at room temperature for $10 \mathrm{~min}$. Species-specific target probes for Trpv1, Grm2, and Grm3 (Table 2) were combined, applied to neurons, and allowed to hybridize for $2 \mathrm{~h}$ at $40^{\circ} \mathrm{C}$ in a humidified oven. A series of incubations were then performed to amplify hybridized probe signal and label target probes with the assigned fluorescence detection channel (C1-C3). Coverslips were counterstained with DAPI using ProLong Gold Antifade Mountant (Invitrogen). Neurons were imaged at $40 \times$ using a Leica SPE confocal microscope (Leica Microsystems). Fields of interest were identified in the DAPI channel. Fiji (Image J, NIH, RRID: SCR: 002285) software was used to calculate neuron diameter and manually quantify single RNA molecule signals. In the RNAscope assay, each punctate dot represents a single target RNA molecule. However, to reduce the likelihood of false positives, mouse and human neurons were defined as positive for a given RNA target if they had $\geq 4$ or $\geq 2$ puncta, respectively, based on the range in neuron puncta density observed for each species. Although we used the same mouse and human tissues used in both assays (Table 1), neuron populations analyzed using FISH were not identical to those analyzed via calcium imaging.

\section{Statistical analyses}

The experimenter was blind to treatment condition and gene of interest throughout analysis of calcium imaging and in situ hybridization data, respectively. Microsoft Excel, GraphPad Prism, R, and the R package Ime4 (RRID: SCR_015654) were used for data organization and statistical analyses (Bates et al., 2014; Team, 2017). Calcium imaging data were analyzed using (1) unpaired $t$ tests and Bonferroni correction for multiple comparisons and (2) linear mixed-effects model (LMM) analyses. LMM analyses controlled for donor as a random effect and donor sex, donor age, and DIV as fixed effects. As the primary objective of the present study was to make species comparisons, we were not sufficiently powered to evaluate the effects of mouse age or sex on calcium imaging outcomes. Species comparisons of the percentage of capsaicin-responsive neurons and gene transcript expression were made using $\chi^{2}$ tests and Bonferroni correction for multiple comparisons, when appropriate. When describing and discussing species differences in gene transcript expression, we default to mouse mRNA nomenclature. Superscript letters listed with $p$-values correspond to the statistical tests shown in Table 3.

\section{Results}

\section{mGluR2/3 suppress $\mathrm{PGE}_{2}$-induced TRPV1 sensitization in mouse, but not human, sensory neurons}

TRPV1 is sensitized by the cAMP/PKA pathway, which is stimulated by inflammatory mediators such as $\mathrm{PGE}_{2}$ (Lopshire and Nicol, 1998; De Petrocellis et al., 2001; Bhave et al., 2002; Mohapatra and Nau, 2003; Meves, 2006). In contrast, group II mGlu receptor activation inhibits adenylyl cyclase and subsequent cAMP production (Conn and Pin, 1997; Johnson and Schoepp, 2008). To determine whether mGluR2/3 activation blocks TRPV1 sensitization, we quantified capsaicin-induced calcium responses of mouse and human sensory neurons. Two 20-s pulses of $100 \mathrm{~nm}$ capsaicin were bath-applied to DRG neurons, and the degree of TRPV1 sensitization was defined as the response ratio of the peak of the second capsaicin response divided by the peak of the first cap-

Table 3. Statistical analysis

\begin{tabular}{|c|c|c|c|c|}
\hline Location & Data Structure & Type of Test & Comparison & $95 \%$ confidence interval \\
\hline a & Non-normally distributed & $t$ test & Vehicle vs. $\mathrm{PGE}_{2}$ & -0.6862 to -0.2728 \\
\hline$b$ & Non-normally distributed & $t$ test & $\mathrm{PGE}_{2}$ vs. $\mathrm{PGE}_{2}+\mathrm{APDC}$ & 0.1317 to 0.618 \\
\hline & Non-normally distributed & $t$ test & Vehicle vs. $\mathrm{PGE}_{2}+$ APDC & -0.2736 to 0.06428 \\
\hline c & Non-normally distributed & $t$ test & Vehicle vs. $\mathrm{PGE}_{2}$ & -0.5774 to -0.2563 \\
\hline$d$ & $\begin{array}{l}\text { Non-normally distributed } \\
\text { Non-normally distributed }\end{array}$ & $t$ test & $\begin{array}{l}\mathrm{PGE}_{2} \text { vs. } \mathrm{PGE}_{2}+\mathrm{APDC} \\
\text { Vehicle vs. } \mathrm{PGE}_{2}+\mathrm{APDC}\end{array}$ & $\begin{array}{l}-0.4204 \text { to } 0.2717 \\
-0.7953 \text { to }-0.1871\end{array}$ \\
\hline e & Non-normally distributed & Regression & Vehicle vs. $\mathrm{PGE}_{2}$ vs. $\mathrm{PGE}_{2}+\mathrm{APDC}$ & -0.1178 to 0.1284 \\
\hline$f$ & Categorical & Chi-squared $^{a}$ & & 0.5621 to 0.8235 \\
\hline g & $\begin{array}{l}\text { Mouse: non-normally distributed } \\
\text { Human: normally distributed }\end{array}$ & $t$ test & Mouse vs. human & -15.17 to -13.08 \\
\hline $\mathrm{h}$ & Categorical & Chi-squared $^{a}$ & & 2.653 to 4.769 \\
\hline 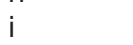 & Categorical & Chi-squared ${ }^{a}$ & & 1.846 to 3.855 \\
\hline & Categorical & Chi-squared $^{a}$ & & 1.047 to 1.967 \\
\hline
\end{tabular}

The D'Agnostino and Pearson normality test was performed, when applicable.

aOdds ratio confidence interval reported. 
A

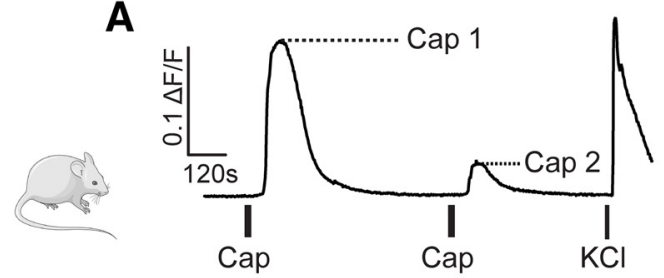

B
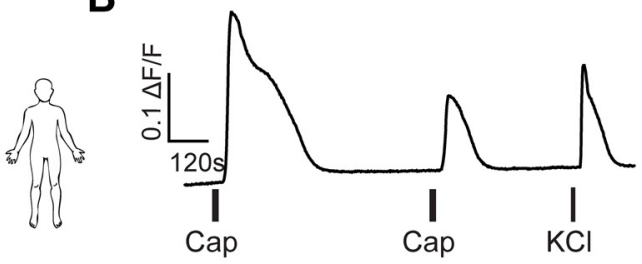

C

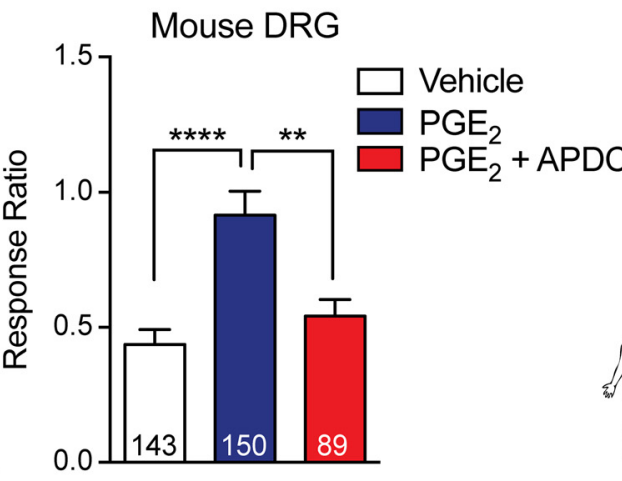

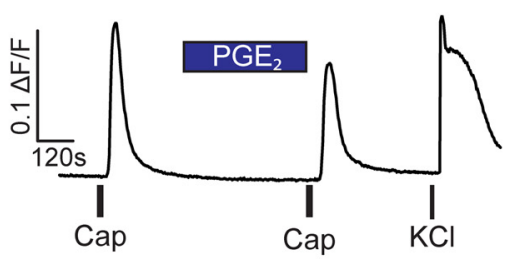

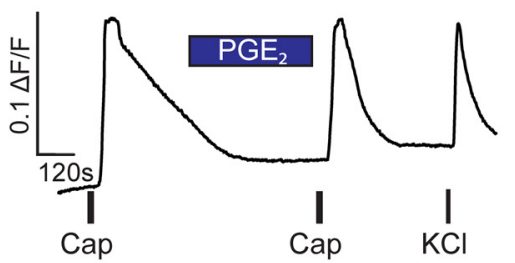

D

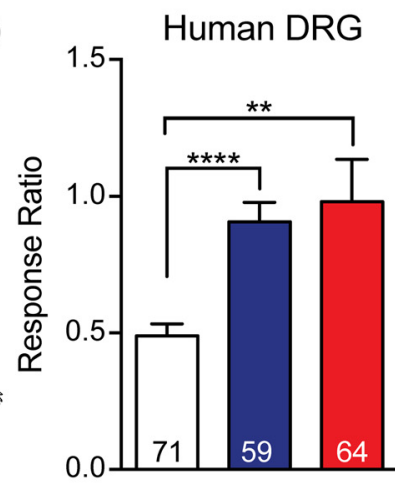

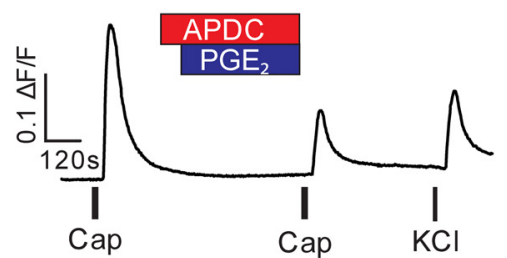

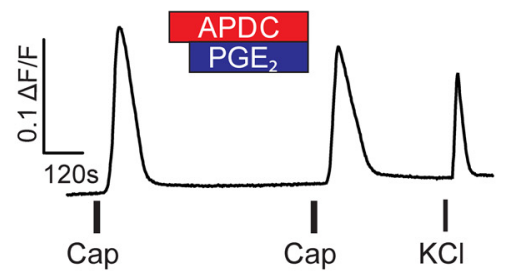

E

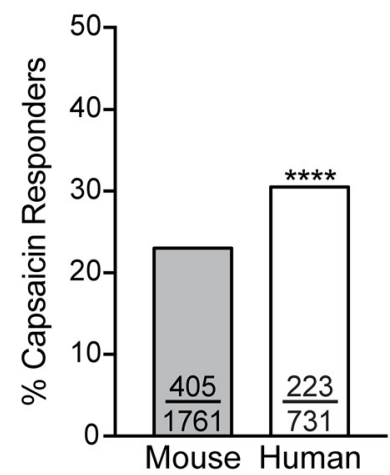

\begin{tabular}{|c|c|c|c|c|}
\hline \multicolumn{5}{|c|}{ Correction of human capsaicin response ratio for donor variability } \\
\hline \multirow[b]{2}{*}{ Paired Conditions } & \multicolumn{2}{|c|}{ t-test } & \multicolumn{2}{|c|}{ LMM + t-test } \\
\hline & $\mathrm{t}$ value & $p$ value & t value & $p$ value \\
\hline Vehicle vs. $\mathrm{PGE}_{2}$ & 5.14 & $3.03 e-06$ & 4.89 & $4.17 \mathrm{e}-05$ \\
\hline $\mathrm{PGE}_{2}$ vs. $\mathrm{PGE}_{2}+\mathrm{APDC}$ & 0.43 & 1.00 & 0.66 & 1.00 \\
\hline Vehicle vs. $\mathrm{PGE}_{2}+\mathrm{APDC}$ & 3.20 & $5.25 e-03$ & 3.05 & $8.76 \mathrm{e}-03$ \\
\hline
\end{tabular}

Figure 1. mGlu2/3 receptor activation blocks $P \mathrm{PE}_{2}$-induced TRPV1 sensitization in mouse, but not human, sensory neurons. Representative traces of $100 \mathrm{~nm}$ capsaicin (Cap)-induced calcium responses in mouse $(\boldsymbol{A})$ and human (B) DRG neurons in response to vehicle (left), $1 \mu \mathrm{M} \mathrm{PGE}_{2}$ (middle), or $1 \mu \mathrm{M} \mathrm{PGE}_{2}+10 \mu \mathrm{M}$ APDC (right). Experiments concluded with a pulse of $50 \mathrm{~mm} \mathrm{KCl}$ to determine cell viability. The degree of TRPV1 sensitization is expressed as a response ratio calculated by dividing the peak amplitude of Cap 2 by the peak amplitude of Cap 1 ( $\boldsymbol{A}$, dashed lines). $\boldsymbol{C}$, In mouse DRG neurons, PGE ${ }_{2}$ significantly increased the capsaicin response ratio compared with vehicle ( $* * * * p=2.1 \times 10^{-5} ; n=143-150$ neurons, $n=4$ preps/condition). Coapplication of APDC with $\mathrm{PGE}_{2}$ blocked this effect and significantly reduced the response ratio compared to $\mathrm{PGE}_{2}$ alone $(* * p=0.0081 ; n=89-150$ neurons, $n=3-4$ preps/condition). $\boldsymbol{D}, \mathrm{PGE}_{2}$ also significantly increased the capsaicin response ratio of human DRG neurons compared with vehicle ( $* * * * p=3.0 \times 10^{-6} ; n=59-71$ neurons, $n=5-6$ donors/condition); whereas coapplication of APDC did not suppress $\mathrm{PGE}_{2}$-induced increases in the capsaicin response ratio ( $p=1, n=59-64$ neurons, $n=6$ donors/condition), which remained significantly greater than vehicle $(* * p=0.0053, n=64-71$ neurons, $n=5-6$ donors/condition). Capsaicin response ratios were compared using unpaired $t$ tests and a Bonferroni correction for multiple comparisons. Data are presented as mean \pm SEM. $\boldsymbol{E}$, Compared with those of mice, a greater percentage of human DRG neurons responded to $100 \mathrm{nM}$ capsaicin $\left(\chi^{2}=15.45\right.$, $* * * * p=8.5 \times 10^{-5}$, mouse: $405 / 1761$ neurons, $n=4$ preps, human: $223 / 731$ neurons, $n=8$ donors). $\boldsymbol{F}$, LMM regression correction for impact of individual donor, as well as donor age and sex, did not alter human capsaicin response ratio analysis statistical outcomes compared with $t$ tests alone.

saicin response. Under vehicle conditions, TRPV1 desensitization is observed in both mouse and human DRG neurons in the form of reduced calcium responses to subsequent capsaicin pulses (Fig. 1A, B). In mouse sensory neurons, bath application of $\mathrm{PGE}_{2}$ between capsaicin pulses significantly increased the capsaicin response ratio compared with vehicle (Fig. $1 A, C^{a}$ ). Coapplication of the selective group II mGluR agonist APDC with $\mathrm{PGE}_{2}$ significantly reduced the response ratio compared with $\mathrm{PGE}_{2}$ alone (Fig. $1 A, C^{b}$ ). As an additional measure of TRPV1 sensitization, we quantified the total calcium load, or area under the curve (AUC) of a subset of capsaicin 
responses. Consistent with the effects on capsaicin peak response ratios, application of $\mathrm{PGE}_{2}$ significantly increased AUC compared with vehicle, and coapplication of APDC with $\mathrm{PGE}_{2}$ significantly reduced this effect (data not shown). These findings confirm our previously published work in cultured sensory neurons obtained from CD-1 mice in which we also demonstrated that suppression of $\mathrm{PGE}_{2}$-induced TRPV1 sensitization by APDC is blocked by the group II mGluR antagonist LY341495, and thus is attributable to mGlu2/3 receptor activation (Yang and Gereau, 2002).

In human sensory neurons, we found that although application of $\mathrm{PGE}_{2}$ between capsaicin pulses significantly increased the capsaicin response ratio compared with vehicle, the response ratio after coapplication of APDC with $\mathrm{PGE}_{2}$ did not significantly differ from application of $\mathrm{PGE}_{2}$ alone (Fig. $1 B, D^{\mathrm{c}, \mathrm{d}}$ ). We observed similar results for total calcium load of capsaicin responses (data not shown). Unlike rodents used in preclinical studies, human organ donors display wide demographic and genetic diversity. To correct for between-donor heterogeneity, we performed a LMM regression. As the effect of age and sex on human sensory neuron physiology is of broad interest to pain researchers, these parameters were included as covariates in our LMM regression. Interestingly, we found that correcting for impact of individual donor, as well as donor age and sex, did not alter our capsaicin response ratio outcome (Fig. 1F). Moreover, LMM regression analysis indicated that the day in vitro at which calcium imaging experiments were performed did not influence capsaicin response ratios for any of the conditions tested $\left(t=0.105, p=0.9182^{\mathrm{e}}\right)$. Taken together, these results demonstrate that mGluR2/3 activation suppresses $\mathrm{PGE}_{2}$-induced TRPV1 sensitization in mouse, but not human, sensory neurons.

We were also interested in whether the same percentage of mouse and human sensory neurons respond to capsaicin. A neuron was defined as capsaicin responsive if it responded to either the first or second pulse of capsaicin. Notably, compared with vehicle conditions, application of $\mathrm{PGE}_{2}$ did not increase the number of neurons that did not respond to the first pulse of capsaicin but did respond to the second pulse of capsaicin in either species. Therefore, data were pooled across treatment conditions for calculations of percentage of capsaicinresponsive neurons. Of the total number of sensory neurons evaluated in calcium imaging studies, $23.0 \%$ of mouse sensory neurons versus $30.5 \%$ of human sensory neurons responded to $100 \mathrm{nM}$ capsaicin, indicating that human sensory neurons are modestly more capsaicin responsive (Fig. $\left.1 E^{f}\right)$. These results are consistent with our initial observations that human sensory neurons exhibit greater chemosensitivity to algogens and pruritogens compared with rodents (Davidson et al., 2014). In the present study, we chose to use $100 \mathrm{~nm}$ capsaicin to test for modulation of TRPV1 desensitization. Previous studies using higher concentrations of capsaicin (200 nM to $1 \mu \mathrm{M}$ ) indicate that capsaicin elicits calcium responses in a greater proportion of mouse DRG and trigeminal neurons, ranging from $30 \%$ to $70 \%$ (Davis et al., 2000; Elitt et al.,
2008; Barabas and Stucky, 2013; Ren et al., 2014; Valtcheva et al., 2015; Mohammed et al., 2017).

\section{Mouse and human sensory neurons share similar Trpv1, Grm2, and Grm3 expression and coexpression profiles}

We hypothesized that the observed species differences in mGluR2/3 functional modulation of TRPV1 could be due to reduced coexpression between TRPV1 and mGlu2 and/or mGlu3 receptors in human versus mouse sensory neurons. We previously demonstrated mGluR2 immunoreactivity in human sensory neurons (Davidson et al., 2016). However, because of the lack of highly selective mGluR3 antibodies suitable for immunohistochemistry (García-Bea et al., 2016), we assessed expression of TRPV1, mGluR2, and mGluR3 mRNA transcripts (referred to as Trpv1, Grm2, and Grm3, respectively) in dissociated sensory neurons using RNAscope FISH. The mouse DRG neurons evaluated in FISH studies ranged from 10.0 to $35.5 \mu \mathrm{m}$ in diameter, with a mean diameter of $17.7 \pm 0.2$ $\mu \mathrm{m}$ for the total population and $20.3 \pm 0.4 \mu \mathrm{m}$ for Trpv $1^{+}$ neurons (Fig. 2A). In comparison, human DRG neurons ranged from 10.0 to $56.3 \mu \mathrm{m}$ in diameter, with a mean diameter of $31.9 \pm 0.5 \mu \mathrm{m}$ for the total population and $33.9 \pm 0.9 \mu \mathrm{m}$ for TRPV1 ${ }^{+}$neurons (Fig. 2B). The mean diameter of the total human DRG neuron population was significantly larger than that of mice (Fig. $2 C^{9}$ ). Our findings closely resemble the size distribution of mouse DRG neurons reported previously (Dirajlal et al., 2003; Barabas et al., 2012; O'Brien et al., 2015). Previous human studies show that the average sensory neuron diameter in unfixed tissues is between $\sim 40$ and $60 \mu \mathrm{m}$ (Anand et al., 2006; Davidson et al., 2014; Xu et al., 2015; Han et al., 2016; Zhang et al., 2017), further highlighting the species difference in sensory neuron size.

With respect to mRNA expression, of the total population of mouse DRG neurons, $37.2 \%$ of neurons were positive for the Trpv1 gene transcript, $61.5 \%$ were positive for Grm2, and 30.9\% were positive for Grm3 (Fig. 2D). Similar transcript expression was observed in human sensory neurons, with $32.2 \%$ of all neurons positive for TRPV1, 52.7\% positive for GRM2, and $29.5 \%$ positive for GRM3 (Fig. 2E). Notably, a significantly greater percentage of total DRG neurons expressed Grm2 compared to Grm3 in both mice $\left(\chi^{2}=74.56, p=1.0 \times 10^{-15} \mathrm{~h}\right)$ and humans $\left(\chi^{2}=28.83, p=8.0 \times 10^{-8}\right)$. Although there was a trend toward an increased percentage of $\mathrm{Grm}^{+}$neurons in mouse compared with human DRG $\left(\chi^{2}=2.229\right.$ with Bonferroni correction, $\left.p=0.077^{j}\right)$, there were no significant species differences in the expression of the transcripts of interest.

Analysis of transcript coexpression showed that the majority of $\operatorname{Trpv} 1^{+}$mouse DRG neurons coexpressed Grm2, Grm3, or both. To elaborate, $33.3 \%$ of Trpv1 ${ }^{+}$neurons coexpressed Grm2, 7.5\% coexpressed Grm3, and $44.2 \%$ coexpressed both Grm2 and Grm3 (Fig. 2F). Of TRPV1 ${ }^{+}$ human DRG neurons, $41.0 \%$ coexpressed GRM2, 8.4\% coexpressed GRM3, and 32.5\% coexpressed both GRM2 and GRM3 (Fig. 2G). No significant species differences were observed in the coexpression of Trpv1 with Grm2 

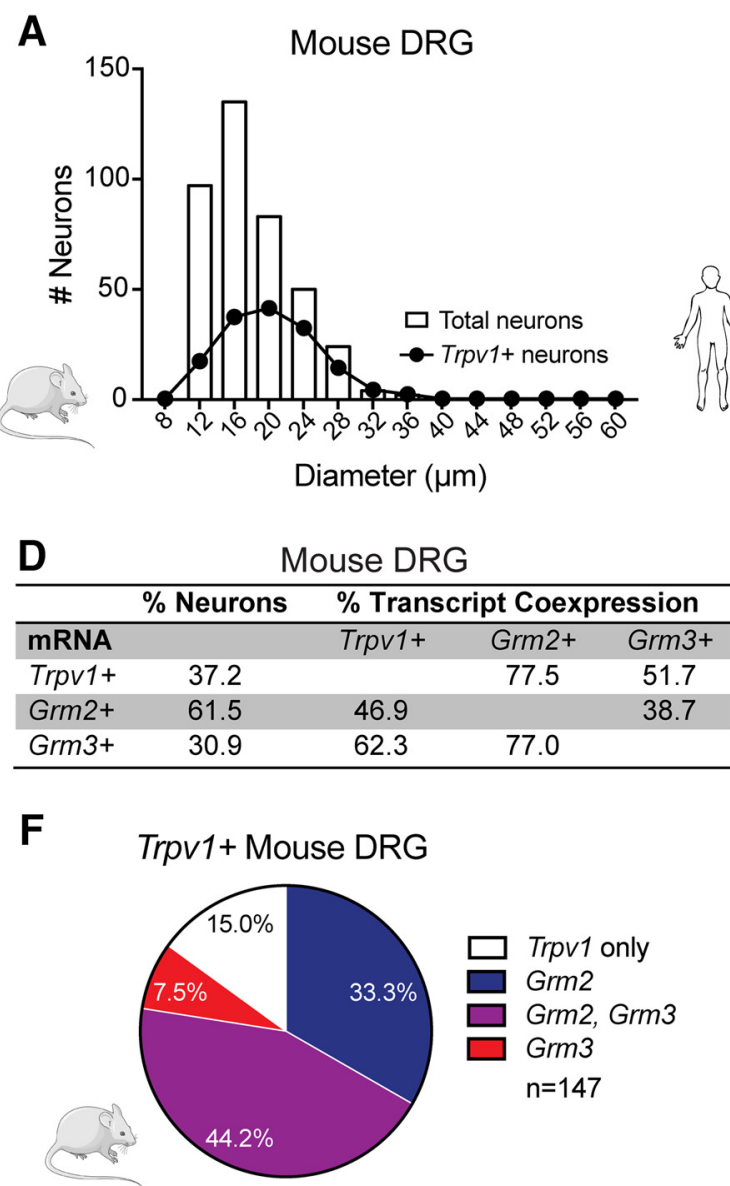
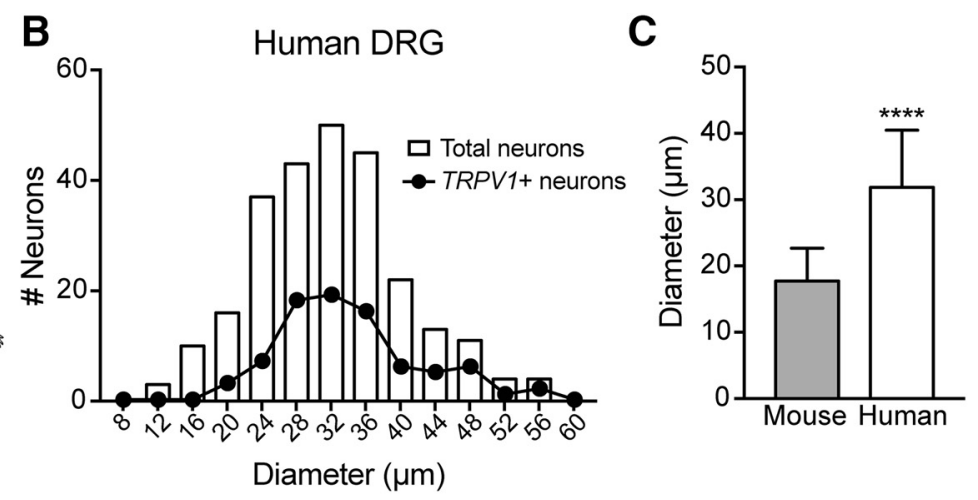

$\mathbf{E}$

\begin{tabular}{|c|c|c|c|c|}
\hline \multirow[b]{2}{*}{ mRNA } & \multirow[t]{2}{*}{$\%$ Neurons } & \multicolumn{3}{|c|}{ \% Transcript Coexpression } \\
\hline & & TRPV1+ & GRM2+ & GRM3+ \\
\hline TRPV1+ & 32.2 & & 73.5 & 40.9 \\
\hline GRM2+ & 52.7 & 44.9 & & 38.2 \\
\hline GRM3+ & 29.5 & 44.7 & 68.4 & \\
\hline
\end{tabular}

$\mathbf{G}$

TRPV1+ Human DRG

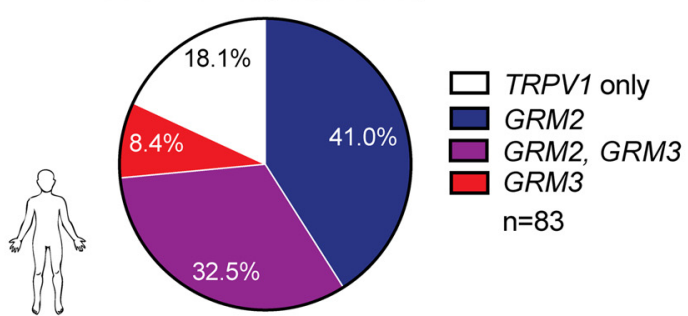

Figure 2. Expression of Trpv1, Grm2, and Grm3 mRNA transcripts in dissociated mouse and human sensory neurons. A, Size distribution of total and Trpv $1^{+}$mouse DRG neuron populations; mean diameter of total neurons: $17.7 \pm 0.2 \mu \mathrm{m}(n=395$ neurons, $n=4$ preps), mean diameter of Trpv1 ${ }^{+}$neurons: $20.3 \pm 0.4 \mu \mathrm{m}\left(n=147\right.$ neurons). $\boldsymbol{B}$, Size distribution of total and TRPV1 ${ }^{+}$human DRG neuron populations; mean diameter of total neurons: $31.9 \pm 0.5 \mu \mathrm{m}$ ( $n=258$ neurons, $n=5$ donors), mean diameter of TRPV1 ${ }^{+}$ neurons: $33.9 \pm 0.9 \mu \mathrm{m}(n=83$ neurons). Data are reported as mean \pm SEM. $\boldsymbol{C}$. The mean diameter of total human DRG neurons was significantly larger than that of total mouse DRG neurons (unpaired $t$ test, $* * * * p=1.0 \times 10^{-14}$ ). Data are presented as mean \pm SD. Percentage of total mouse $(\boldsymbol{D})$ and human $(\boldsymbol{E})$ DRG neurons that expressed Trpv1, Grm2, and Grm3, as well as the percentage of neurons that coexpressed one mRNA transcript with another. Pie charts showing the percentage of $\operatorname{Trpv} 1^{+}$mouse $(\boldsymbol{F})$ and human (G) DRG neurons that coexpressed Grm2, Grm3, or both transcripts. No significant differences in gene transcript expression of total neurons or $\operatorname{Trpv} 1^{+}$neuron subpopulations were observed between species.

and/or Grm3 gene transcripts. Thus, these findings suggest that the absence of mGluR2/3-induced suppression of TRPV1 sensitization in human DRG neurons cannot be explained by reduced coexpression of TRPV1 with group II mGluRs at the gene transcript level.

\section{Discussion}

Peripheral targets for pain relief are greatly desired given the centrally mediated side effects, including addiction and misuse of current frontline analgesics such as opioids. In both mice and humans, activation of group II mGluRs blocks sensory neuron membrane hyperexcitability elicited by the inflammatory mediator $\mathrm{PGE}_{2}$ (Davidson et al., 2016). In the present study, we demonstrate that suppression of inflammation-induced TRPV1 sensitization represents an additional mechanism by which mGluR2/3 reduce peripheral sensitization in mouse, but not human, sensory neurons. We further show equivalent colocalization of Trpv1 with Grm2 and Grm3 mRNA tran- scripts in mouse and human DRG neurons, suggesting that disparities in coexpression do not explain species differences in the functional modulation of TRPV1 by group II mGluRs. These findings indicate that although mGluR2/3 activation decreases sensory neuron sensitization in both mice and humans, mechanisms of peripheral analgesia are not fully conserved across species.

\section{mGluR2/3 functional differences in mouse and human sensory neurons}

That the mGlu2/3 receptor agonist APDC did not suppress $\mathrm{PGE}_{2}$-induced TRPV1 sensitization in human DRG neurons was a surprising observation. Foremost, cDNA and amino acid sequences of human and rodent mGluR2 and mGluR3 display at least 90\% homology (Flor et al., 1995; Makoff et al., 1996; Johnson and Schoepp, 2008). In turn, APDC exhibits comparable potency at rodent and human group II mGluRs with respect to inhibition of stimulated cAMP responses (Schoepp et al., 1995). Our recent 
finding that APDC decreases excitability and increases action potential threshold in $\mathrm{PGE}_{2}$-treated sensory neurons of both species further suggests mGluR2/3 functional homology in mouse and human sensory neurons (Davidson et al., 2016). Existing behavioral and in vitro rodent studies strongly suggest that inhibition of cAMPdependent TRPV1 sensitization is another mechanism by which mGluR2/3 can block sensory neuron sensitization (Yang and Gereau, 2002; Du et al., 2008; Carlton et al., $2009,2011)$. Here, we substantiate these findings by demonstrating that APDC blocks $\mathrm{PGE}_{2}$-induced TRPV1 sensitization in C57BL/6J mice. However, this observation did not translate in human sensory neurons despite the apparent similarities of mGluR2/3 function between species.

There are multiple potential explanations for the lack of translation of mGluR2/3 functional modulation of TRPV1 from mice to humans. For example, in addition to PKA, $\mathrm{PGE}_{2}$-induced intracellular signaling cascades can activate other kinases known to sensitize TRPV1, including PKC and c-Src kinase (Vellani et al., 2001; Numazaki et al., 2002; Jin et al., 2004; Moriyama et al., 2005). Thus, although we observed $\mathrm{PGE}_{2}$-induced sensitization of capsaicin responses in both mouse and human sensory neurons, it is possible that in contrast to mice, $\mathrm{PGE}_{2}$-induced TRPV1 sensitization in humans occurs via a predominantly PKA-independent pathway that is not influenced by mGlu2/3 receptor activation. Further investigation of the intracellular mechanisms that underlie $\mathrm{PGE}_{2}$-induced TRPV1 sensitization in human sensory neurons is therefore needed.

Another important consideration is that although we observed equivalent coexpression of Grm2 and Grm3 gene transcripts in Trpv1 $1^{+}$mouse and human DRG neurons, whether equivalent coexpression of TRPV1 and mGluR2/3 also extends to the protein level remains unclear. For instance, it is possible that species differences exist in the regulation of translation, posttranslational modifications, and subcellular compartmentalization of TRPV1 and mGlu2/3 receptors. TRPV1 immunoreactivity has been demonstrated in human DRG neurons, peripheral nerves, and intra-epidermal nerve fibers (Anand et al., 2006, 2015; Facer et al., 2007; Li et al., 2015; Han et al., 2016). However, until selective mGluR2 and mGluR3 antibodies suitable for immunohistochemistry are generated, our ability to evaluate the coexpression and subcellular localization of group II mGluRs with TRPV1 remains limited. Importantly, although mGlu2/3 receptor activation does not modulate sensitization of TRPV1 in humans, the expression of GRM2 and/or GRM3 in the majority of small-diameter $(<50 \mu \mathrm{m}) T R P V 1^{+}$human DRG neurons suggests that these receptors are well positioned to modulate nociceptor activity by alternative mechanisms. Thus, mGluR2/3 remain putative human peripheral analgesic targets.

\section{Sensory neuron expression of Grm2, Grm3, and Trpv1}

Existing immunohistochemical analyses of rodent DRG neurons demonstrate high colocalization of group II mGlu receptors with TRPV1, with 93\% of TRPV1-positive neurons expressing mGluR2/3 and effectively all mGluR2/3- positive neurons expressing TRPV1 (Carlton et al., 2009). Here we demonstrate that the majority $(\geq 81 \%)$ of Trpv $1^{+}$ mouse and human sensory neurons also express Grm2 and Grm3 gene transcripts. In contrast, we found that in both mice and humans, only a subset $(45 \%-62 \%)$ of either $\mathrm{Grm} 2^{+}$or $\mathrm{Grm}^{+}{ }^{+}$neurons also expressed the Trpv1 transcript. Importantly, prior immunohistochemistry studies using nonselective mGluR2/3 antibodies and RNAsequencing analysis of homogenized DRG precluded analyses of which group II mGlu receptor is predominantly expressed in sensory neurons and to what extent mGluR2 and mGluR3 are coexpressed within the same neurons. We show for the first time that Grm2 is more highly expressed than Grm3 in mouse and human sensory neurons. Further, while Grm2 and Grm3 are coexpressed in a subset $(38 \%-77 \%)$ of mouse and human sensory neurons, the transcripts are also expressed individually. These findings suggest that mGluR2 may play a larger role in modulating nociceptor excitability than mGluR3. Indeed, previous behavioral studies demonstrate that the analgesic efficacy of group II mGlu receptor agonists persists in mGluR3 ${ }^{-/-}$, but not mGluR2 ${ }^{-/-}$, mice, suggesting a greater role for mGluR2 than mGluR3 in pain regulation (Zammataro et al., 2011). As repeated dosing with group II mGlu receptor agonists causes analgesic tolerance in rodents (Jones et al., 2005; Chiechio et al., 2009), alternative strategies to reinforce endogenous activation of mGluR2 may be required to effectively target group II mGlu receptors for clinical pain relief. Our results suggest that recently developed mGluR2-specific positive allosteric modulators may be promising agents for blockade of peripheral sensitization (Galici et al., 2006; Asseri et al., 2015).

\section{Distinctions between human and rodent sensory neurons}

In addition to differences in mGlu2/3 receptor function, we demonstrate that human sensory neurons possess distinct fundamental properties including increased diameter and an increased percentage of capsaicin-responsive neurons compared with those of mice. Using calcium imaging, we found that $30.5 \%$ of human DRG neurons responded to $100 \mathrm{~nm}$ capsaicin. However, it is possible that a larger proportion of human sensory neurons expresses TRPV1 and/or responds to capsaicin. For instance, previous immunohistochemical analysis of human DRG showed that roughly $55 \%$ of all DRG neurons were TRPV1-immunoreactive (Anand et al., 2006). Further, in calcium imaging experiments, $\sim 60 \%$ of ganglionectomized DRG neurons removed due to chronic intractable pain responded to $100 \mathrm{nM}$ capsaicin (Baumann et al., 1996, 2004). These findings suggest that an even greater species difference in capsaicin-responsive neurons may exist between mice and humans than we report here. Of course, variability in experimental conditions or donor demographics, genetic diversity, and pain-related health conditions could underlie differences in TRPV1 expression across human studies. For this reason, developing an extensive donor tissue bank to investigate DRG neuron gene and protein expression as well as to further characterize sensory neuron subpopulations will allow for more 
complete comparisons between species, and perhaps more interestingly, among donor subpopulations.

Nevertheless, while only a small number of comparative studies of rodent and human sensory neurons have been conducted, it is becoming increasingly clear that species differences exist in gene expression, ion channel properties, and action potential firing patterns (Baldo et al., 2013; Han et al., 2015; Chang et al., 2017; Ray et al., 2017; Rostock et al., 2017; Zhang et al., 2017). Therefore, human sensory neurons represent a vital tool for improving our understanding of human nociceptor physiology under both normal and pathologic conditions. Further, using human sensory neurons to assess the validity of putative analgesic targets identified in rodents may lead to increased translational success of preclinical findings.

\section{References}

Anand U, Otto WR, Casula MA, Day NC, Davis JB, Bountra C, Birch $R$, Anand P (2006) The effect of neurotrophic factors on morphology, TRPV1 expression and capsaicin responses of cultured human DRG sensory neurons. Neurosci Lett 399:51-56. CrossRef Medline

Anand $U$, Yiangou $Y$, Sinisi M, Fox M, MacQuillan A, Quick T, Korchev YE, Bountra C, McCarthy T, Anand P (2015) Mechanisms underlying clinical efficacy of Angiotensin II type 2 receptor (AT2R) antagonist EMA401 in neuropathic pain: clinical tissue and in vitro studies. Mol Pain 11:38. CrossRef Medline

Asseri KA, Puil E, Schwarz SKW, MacLeod BA (2015) Group II metabotropic glutamate receptor antagonism prevents the antiallodynic effects of R-isovaline. Neuroscience 293:151-156. CrossRef

Baldo G, Wozniak DF, Ohlemiller KK, Zhang Y, Giugliani R, Ponder KP (2013) Retroviral-vector-mediated gene therapy to mucopolysaccharidosis I mice improves sensorimotor impairments and other behavioral deficits. J Inherit Metab Dis 36:499-512. CrossRef Medline

Barabas ME, Kossyreva EA, Stucky CL (2012) TRPA1 is functionally expressed primarily by IB4-binding, non-peptidergic mouse and rat sensory neurons. PLoS One 7:1-12. CrossRef

Barabas ME, Stucky CL (2013) TRPV1, but not TRPA1, in primary sensory neurons contributes to cutaneous incision-mediated hypersensitivity. Mol Pain 9:9. CrossRef

Bates D, Mächler M, Bolker B, Walker S (2014) Fitting linear mixedeffects models using Ime4. J Stat Softw 67:1-48.

Baumann TK, Burchiel KJ, Ingram SL, Martenson ME (1996) Responses of adult human dorsal root ganglion neurons in culture to capsaicin and low pH. Pain 65:31-38. Medline

Baumann TK, Chaudhary P, Martenson ME (2004) Background potassium channel block and TRPV1 activation contribute to proton depolarization of sensory neurons from humans with neuropathic pain. Eur J Neurosci 19:1343-1351. CrossRef

Bhave G, Zhu W, Wang H, Brasier D, Oxford GS, Gereau RW (2002) cAMP-dependent protein kinase regulates desensitization of the capsaicin receptor (VR1) by direct phosphorylation. Neuron 35: 721-731. Medline

Boye Larsen D, Ingemann Kristensen G, Panchalingam V, Laursen JC, Nørgaard Poulsen J, Skallerup Andersen M, Kandiah A, Gazerani $P$ (2014) Investigating the expression of metabotropic glutamate receptors in trigeminal ganglion neurons and satellite glial cells: implications for craniofacial pain. J Recept Signal Transduct Res 34:1-9. CrossRef

Carlton S, Hargett G (2007) Colocalization of metabotropic glutamate receptors in rat dorsal root ganglion cells. J Comp Neur 501:780789. CrossRef

Carlton S, Hargett G, Coggeshall R (2001) Localization of metabotropic glutamate receptors $2 / 3$ on primary afferent axons in the rat. Neuroscience 105:957-969. Medline
Carlton SM, Du J, Zhou S (2009) Group II metabotropic glutamate receptor activation on peripheral nociceptors modulates TRPV1 function. Brain Res 1248:86-95. CrossRef Medline

Carlton SM, Zhou S, Govea R, Du J (2011) Group II/III metabotropic glutamate receptors exert endogenous activity-dependent modulation of TRPV1 receptors on peripheral nociceptors. J Neurosci 31:12727-12737. CrossRef Medline

Caterina MJ, Leffler A, Malmberg AB, Martin W, Trafton J, PetersenZeitz K, Koltzenburg M, Basbaum Al, Julius D (2000) Impaired nociception and pain sensation in mice lacking the capsaicin receptor. Science 288:306-313. Medline

Caterina MJ, Schumacher MA, Tominaga M, Rosen TA, Levine JD, Julius D (1997) The capsaicin receptor: a heat-activated ion channel in the pain pathway. Nature 389:816-824. CrossRef Medline

Chang W, Berta T, Kim YH, Lee S, Lee SY, Ji RR (2017) Expression and role of voltage-gated sodium channels in human dorsal root ganglion neurons with special focus on Nav1.7, species differences, and regulation by paclitaxel. Neurosci Bull 1-9.

Chiechio S (2016) Modulation of chronic pain by metabotropic glutamate receptors. Adv Pharmacol 75:63-89. CrossRef Medline

Chiechio S, Zammataro M, Morales ME, Busceti CL, Drago F, Gereau RW, Copani A, Nicoletti F (2009) Epigenetic modulation of mGlu2 receptors by histone deacetylase inhibitors in the treatment of inflammatory pain. Mol Pharmacol 75:1014-1020. CrossRef Medline

Conn PJ, Pin JP (1997) Pharmacology and functions of metabotropic glutamate receptors. Annu Rev Pharmacol Toxicol 37:205-237. CrossRef Medline

Davidson S, Copits BA, Zhang J, Page G, Ghetti A, Gereau RW (2014) Human sensory neurons: membrane properties and sensitization by inflammatory mediators. Pain 155:1861-1870. CrossRef Medline

Davidson S, Golden JP, Copits BA, Ray PR, Vogt SK, Price TJ, Schmidt RE, Ghetti A, Gereau RW IV (2016) Group 2 mGluRs suppress hyperexcitability in mouse and human nociceptors. Pain 157:2081-2088. CrossRef

Davis JB, et al. (2000) Vanilloid receptor-1 is essential for inflammatory thermal hyperalgesia. Nature 405:183-187. CrossRef Medline

De Petrocellis L, Harrison S, Bisogno T, Tognetto M, Brandi I, Smith GD, Creminon C, Davis JB, Geppetti P, Di Marzo V (2001) The vanilloid receptor (VR1)-mediated effects of anandamide are potently enhanced by the cAMP-dependent protein kinase. J Neurochem 77:1660-1663. Medline

Dirajlal S, Pauers LE, Stucky CL (2003) Differential response properties of IB(4)-positive and -negative unmyelinated sensory neurons to protons and capsaicin. J Neurophysiol 89:513-524. CrossRef Medline

Du J, Zhou S, Carlton SM (2008) Group II metabotropic glutamate receptor activation attenuates peripheral sensitization in inflammatory states. Neuroscience 154:754-766. CrossRef Medline

Elitt CM, Malin SA, Koerber HR, Davis BM, Albers KM (2008) Overexpression of artemin in the tongue increases expression of TRPV1 and TRPA1 in trigeminal afferents and causes oral sensitivity to capsaicin and mustard oil. Brain Res 1230:80-90. CrossRef Medline

Facer P, Casula MA, Smith GD, Benham CD, Chessell IP, Bountra C, Sinisi M, Birch R, Anand P (2007) Differential expression of the capsaicin receptor TRPV1 and related novel receptors TRPV3, TRPV4 and TRPM8 in normal human tissues and changes in traumatic and diabetic neuropathy. BMC Neurol 7:11. CrossRef Medline

Flor PJ, Lindauer K, Püttner I, Rüegg D, Lukic S, Knöpfel T, Kuhn R (1995) Molecular cloning, functional expression and pharmacological characterization of the human metabotropic glutamate receptor type 2. Eur J Neurosci 7:622-629. Medline

Galici R, Jones C, Hemstapat K (2006) Biphenyl-indanone A, a positive allosteric modulator of the metabotropic glutamate receptor subtype 2, has antipsychotic-and anxiolytic-like effects in mice. J Pharmacol Exp Ther 318:173-185. CrossRef Medline 
García-Bea A, Walker MA, Hyde TM, Kleinman JE, Harrison PJ, Lane TA (2016) Metabotropic glutamate receptor 3 (mGlu3; mGluR3; GRM3) in schizophrenia: antibody characterisation and a semiquantitative western blot study. Schizophr Res 177:18-27. CrossRef

Han C, Estacion M, Huang J, Vasylyev DV, Zhao P, Dib-Hajj S, Waxman SG (2015) Human Nav1.8: enhanced persistent and ramp currents contribute to distinct firing properties of human DRG neurons. J Neurophysiol 113:3172-3185. CrossRef

Han Q, Kim YH, Wang X, Liu D, Zhang ZJ, Bey AL, Lay M, Chang W, Berta T, Zhang Y, Jiang YH, Ji RR (2016) SHANK3 deficiency impairs heat hyperalgesia and TRPV1 signaling in primary sensory neurons. Neuron 92:1279-1293. CrossRef Medline

Jin X, Morsy N, Winston J, Pasricha PJ, Garrett K, Akbarali HI (2004) Modulation of TRPV1 by nonreceptor tyrosine kinase, c-Src kinase. Am J Physiol Cell Physiol 287:C558-C563. CrossRef Medline

Johnson M, Schoepp DD (2008) Group II metabotropic glutamate receptors (mGlu2 and mGlu3). In: Gereau RW, Swanson G, editors. The Glutamate Receptors. Totowa, NJ: Humana Press, 2008; pp. $465-488$.

Johnson MP, Muhlhauser MA, Nisenbaum ES, Simmons RMA, Forster BM, Knopp KL, Yang L, Morrow D, Li DL, Kennedy JD, Swanson S, Monn JA (2017) Broad spectrum efficacy with LY2969822, an oral prodrug of metabotropic glutamate 2/3 receptor agonist LY2934747, in rodent pain models. Br J Pharmacol 174:822-835. CrossRef

Jones CK, Eberle EL, Peters SC, Monn JA, Shannon HE (2005) Analgesic effects of the selective group II (mGlu2/3) metabotropic glutamate receptor agonists LY379268 and LY389795 in persistent and inflammatory pain models after acute and repeated dosing. Neuropharmacology 49:206-218. CrossRef

Kissin I (2010) The development of new analgesics over the past 50 years: a lack of real breakthrough drugs. Anesth Analg 110:780789. CrossRef Medline

Kolber BJ (2015) mGluRs head to toe in pain. Prog Mol Biol Transl Sci 131:281-324. CrossRef Medline

Le Bars D, Gozariu M, Cadden SW (2001) Animal models of nociception. Pharmacol Rev 53:597-652. Medline

$\mathrm{Li} \mathrm{Y}$, et al. (2015) The cancer chemotherapeutic paclitaxel increases human and rodent sensory neuron responses to TRPV1 by activation of TLR4. J Neurosci 35:13487-13500. CrossRef Medline

Lopshire JC, Nicol GD (1998) The cAMP transduction cascade mediates the prostaglandin E2 enhancement of the capsaicin-elicited current in rat sensory neurons: whole-cell and single-channel studies. J Neurosci 18:6081-6092. Medline

Makoff A, Lelchuk R, Oxer M, Harrington K, Emson P (1996) Molecular characterization and localization of human metabotropic glutamate receptor type 41. Mol Brain Res 37:239-248. Medline

Mao $J$ (2012) Current challenges in translational pain research. Trends Pharmacol Sci 33:568-573. CrossRef Medline

Meves H (2006) The action of prostaglandins on ion channels. Curr Neuropharmacol 4:41-57. Medline

Mohammed ZA, Doran C, Grundy D, Nassar MA (2017) Veratridine produces distinct calcium response profiles in mouse dorsal root ganglia neurons. Sci Rep 7:45221. CrossRef Medline

Mohapatra DP, Nau C (2003) Desensitization of capsaicin-activated currents in the vanilloid receptor TRPV1 is decreased by the cyclic AMP-dependent protein kinase pathway. J Biol Chem 278:5008050090. CrossRef Medline

Moore A, Derry S, Eccleston C, Kalso E (2013) Expect analgesic failure; pursue analgesic success. Br Med J 346:f2690. CrossRef

Moriyama T, Higashi T, Togashi K, lida T, Segi E, Sugimoto Y, Tominaga T, Narumiya S, Tominaga M (2005) Sensitization of TRPV1 by EP 1 and IP reveals peripheral nociceptive mechanism of prostaglandins. Mol Pain 1:3. CrossRef

Numazaki M, Tominaga T, Toyooka H, Tominaga M (2002) Direct phosphorylation of capsaicin receptor VR1 by protein kinase $C \varepsilon$ and identification of two target serine residues. J Biol Chem 277:13375-13378. CrossRef Medline
O'Brien DE, Alter BJ, Satomoto M, Morgan CD, Davidson S, Vogt SK, Norman ME, Gereau GB, Demaro JA, Landreth GE, Golden JP, Gereau RW (2015) ERK2 alone drives inflammatory pain but cooperates with ERK1 in sensory neuron survival. J Neurosci 35: 9491-9507.

Osikowicz M, Mika J, Makuch W, Przewlocka B (2008) Glutamate receptor ligands attenuate allodynia and hyperalgesia and potentiate morphine effects in a mouse model of neuropathic pain. Pain 139:117-126. CrossRef

Petralia RS, Wang Y-X, Niedzielski AS, Wenthold RJ (1996) The metabotropic glutamate receptors, MGLUR2 and MGLUR3, show unique postsynaptic, presynaptic and glial localizations. Neuroscience 71:949-976. Medline

R Core Team (2017) R: A language and environment for statistical computing. R Foundation for Statistical Computing, Vienna, Austria.

Ray P, Torck A, Quigley L, Wangzhou A, Neiman M, Price TJ (2017) Comparative transcriptome profiling of the human and mouse dorsal root ganglia: An RNA-seq-based resource for pain and sensory neuroscience research. bioRxiv doi: https://doi.org/ 10.1101/165431.

Ren A-J, Wang K, Zhang H, Liu A, Ma X, Liang Q, Cao D, Wood JN, He DZ, Ding Y-Q, Yuan W-J, Xie Z, Zhang WJ (2014) ZBTB20 regulates nociception and pain sensation by modulating TRP channel expression in nociceptive sensory neurons. Nat Commun 5:4984. CrossRef Medline

Rostock C, Schrenk-Siemens K, Pohle J, Siemens J (2017) Human vs. mouse nociceptors-similarities and differences. Neuroscience CrossRef

Sapio MR, Goswami SC, Gross JR, Mannes AJ, ladarola MJ (2016) Transcriptomic analyses of genes and tissues in inherited sensory neuropathies. Exp Neurol 283:375-395. CrossRef Medline

Schoepp DD, Johnson BG, Salhoff CR, Valu MJ, Desai MA, Burnett JP, Mayne NG, Monn JA (1995) Selective inhibition of forskolinstimulated cyclic AMP formation in rat hippocampus by a novel mGluR agonist, 2R,4R-4-aminopyrrolidine-2,4-dicarboxylate. Neuropharmacology 34:843-850. CrossRef

Sharpe EF, Kingston AE, Lodge D, Monn JA, Headley PM (2002) Systemic pre-treatment with a group II mGlu agonist, LY379268, reduces hyperalgesia in vivo. $\mathrm{Br} \mathrm{J}$ Pharmacol 135:1255-1262. CrossRef Medline

Simmons RMA, Webster AA, Kalra AB, lyengar S (2002) Group II mGluR receptor agonists are effective in persistent and neuropathic pain models in rats. Pharmacol Biochem Behav 73:419427. CrossRef

Tang FR, Sim MK (1999) Pre- and/or post-synaptic localisation of metabotropic glutamate receptor $1 \mathrm{a}$ (mGluR1a) and $2 / 3$ (mGluR2/3) in the rat spinal cord. Neurosci Res 34:73-78. Medline

Valtcheva MV, Copits BA, Davidson S, Sheahan TD, Pullen MY, McCall JG, Dikranian K, Gereau RW (2016) Surgical extraction of human dorsal root ganglia from organ donors and preparation of primary sensory neuron cultures. Nat Protoc 11:1877-1888. CrossRef Medline

Valtcheva MV, Davidson S, Zhao C, Leitges M, Gereau RW (2015) Protein kinase $\mathrm{C} \delta$ mediates histamine-evoked itch and responses in pruriceptors. Mol Pain 11:1CrossRef Medline

Varney MA, Gereau RW (2002) Metabotropic glutamate receptor involvement in models of acute and persistent pain: prospects for the development of novel analgesics. Curr Drug Targets CNS Neurol Disord 1:283-296. CrossRef

Vellani V, Mapplebeck S, Moriondo A, Davis JB, McNaughton PA (2001) Protein kinase $C$ activation potentiates gating of the vanilloid receptor VR1 by capsaicin, protons, heat and anandamide. J Physiol 534:813-825. Medline

Whiteside GT, Kennedy J (2010) Consideration of pharmacokinetic pharmacodynamic relationships in the discovery of new pain drugs. In: Kruger L, Light A, editors. Translational Pain Research: 
From Mouse to Man. Boca Raton, FL: CRC Press/Taylor \& Francis, 2010.

Woolf CJ (2010) Overcoming obstacles to developing new analgesics. Nat Med 16:1241-1247. CrossRef Medline

Xu Z-Z, Kim YH, Bang S, Zhang Y, Berta T, Wang F, Oh SB, Ji R-R (2015) Inhibition of mechanical allodynia in neuropathic pain by TLR5-mediated A-fiber blockade. Nat Med 21:1326-1331. CrossRef Medline

Yang D, Gereau RW (2002) Peripheral group II metabotropic glutamate receptors (mGluR2/3) regulate prostaglandin E2-mediated sensitization of capsaicin responses and thermal nociception. $J$ Neurosci 22:6388-6393. Medline Medline
Yang D, Gereau RW (2003) Peripheral group II metabotropic glutamate receptors mediate endogenous anti-allodynia in inflammation. Pain 106:411-417. Medline

Zammataro M, Chiechio S, Montana MC, Traficante A, Copani A, Nicoletti F, Gereau RW (2011) mGlu2 metabotropic glutamate receptors restrain inflammatory pain and mediate the analgesic activity of dual mGlu2/ mGlu3 receptor agonists. Mol Pain 7:6. CrossRef Medline

Zhang X, Priest BT, Belfer I, Gold MS (2017) Voltage-gated Na+ currents in human dorsal root ganglion neurons. eLife 6:1-23.

Zhang XL, Lee KY, Priest BT, Belfer I, Gold MS (2015) Inflammatory mediator-induced modulation of GABAA currents in human sensory neurons. Neuroscience 310:401-409. CrossRef Medline 